\title{
Association between subclinical hypothyroidism and depression: an updated systematic review and meta- analysis
}

Huai Heng Loh ${ }^{1 *+}$, Lee Ling Lim ${ }^{2+}$, Anne Yee ${ }^{3}$ and Huai Seng Loh ${ }^{4}$

\begin{abstract}
Background: Although depression is associated with changes in the hypothalamic-pituitary-thyroid axis, its relationship with subclinical hypothyroidism $(\mathrm{SCH})$ is controversial. To date, there is a lack of data on the improvement of depressive symptoms with levothyroxine therapy among individuals with coexistent SCH.

Methods: We conducted a meta-analysis to evaluate the association between SCH and depression including 1) the prevalence of depression in SCH (with a sub-analysis of the geriatric cohort), 2) thyroid stimulating hormone (TSH) level among patients with depression and 3) the effect of levothyroxine therapy among patients with SCH and coexistent depression.

Results: In a pooled analysis of 12,315 individuals, those with SCH had higher risk of depression than euthyroid controls (relative risk 2.35, 95\% confidence intervals [CI], 1.84 to 3.02; $p<0.001$ ). Geriatric cohort with SCH had a 1.7fold higher risk of depression compared with healthy controls (odds ratio $1.72, \mathrm{Cl}, 1.10$ to $2.70 ; p=0.020$ ). There was no difference in the mean TSH level between individuals with depression and healthy controls $(2.30 \pm 1.18$ vs. 2.13 $\pm 0.72 \mathrm{mIU} / \mathrm{L}, p=0.513)$. In individuals with $\mathrm{SCH}$ and coexistent depression, levothyroxine therapy was neither associated with improvement in the Beck Depression Inventory scoring (pooled $d+=-1.05, \mathrm{Cl}-2.72$ to $0.61 ; p=0$. 215) nor Hamilton Depression Rating Scale (pooled $d+=-2.38, \mathrm{Cl}-4.86$ to $0.10 ; p=0.060$ ).

Conclusion: SCH has a negative impact on depression. Early and routine screening of depression is essential to prevent morbidity and mortality. However, the use of levothyroxine among patients with $\mathrm{SCH}$ and coexistent depression needs to be individualized.
\end{abstract}

Keywords: Subclinical hypothyroidism, Depression, Thyroid stimulating hormone, Levothyroxine

\section{Background}

Neuropsychiatric disorders account for approximately 14\% of the global burden of disease [1]. Depression, being one of the common chronically disabling disorders, can lead to poor quality of life $[1,2]$. On the other hand, thyroid hormones (free triiodothyronine [fT3] and free thyroxine [fT4]) which are widely distributed in the central nervous system, regulate the neuronal growth and form synapses

\footnotetext{
*Correspondence: hhloh@unimas.my

${ }^{\dagger}$ Huai Heng Loh and Lee Ling Lim contributed equally to this work.

${ }^{1}$ Faculty of Medicine and Health Sciences, University of Malaysia

Sarawak(UNIMAS), Jalan Dato Muhammad Musa, 94300 Kota Samarahan,

Sarawak, Malaysia

Full list of author information is available at the end of the article
}

between neurons [3]. Given that depression is known to be associated with changes in the hypothalamic-pituitary-thyroid (HPT) axis [4], studies have reported its positive correlation with overt hypothyroidism [5]. However, its relationship with subclinical hypothyroidism $(\mathrm{SCH})$ is not well established [6].

$\mathrm{SCH}$ is defined as an elevated thyroid stimulating hormone (TSH) with normal fT4 and fT3 levels. It affects 3 to $8.5 \%$ of the general population with a female preponderance, and a higher rate up to $20 \%$ among elderly people $[7,8]$. This diagnosis is often overlooked especially when laboratory tests are not readily available, as these individuals with $\mathrm{SCH}$ tend to present with subtle

(c) The Author(s). 2019 Open Access This article is distributed under the terms of the Creative Commons Attribution 4.0 International License (http://creativecommons.org/licenses/by/4.0/), which permits unrestricted use, distribution, and reproduction in any medium, provided you give appropriate credit to the original author(s) and the source, provide a link to the Creative Commons license, and indicate if changes were made. The Creative Commons Public Domain Dedication waiver (http://creativecommons.org/publicdomain/zero/1.0/) applies to the data made available in this article, unless otherwise stated. 
and non-specific symptoms [9]. The debilitating effect of $\mathrm{SCH}$ on cardiovascular morbidity and mortality has gained increasing attention, suggesting that $\mathrm{SCH}$ is an independent risk factor for atherosclerotic cardiovascular disease $[10,11]$. However, its association with depression remains controversial at large, with some studies indicated that $\mathrm{SCH}$ had the same propensity with overt hypothyroidism, while the others reported conflicting findings $[7,8,12-24]$. These inconsistent results could be attributed to the heterogeneous study populations, small sample size, lack of control arm for comparison and differences in study design.

To date, individuals with $\mathrm{SCH}$ are recommended to be initiated with levothyroxine replacement therapy only when their TSH level is above $10 \mathrm{mIU} / \mathrm{L}$ or if they are symptomatic, attempting pregnancy, have positive thyroid autoimmunity or cardiovascular risk factors, especially hypertension and hyperlipidemia $[25,26]$. However, there is a lack of solid evidence in support of the use of levothyroxine therapy to improve mental health outcomes [27]. Hence, we performed an updated meta-analysis to evaluate the correlation between these two entities and the effect of levothyroxine therapy.

\section{Methods}

We performed a systematic search of all English-language medical literature published from inception till June 2017 using PubMed, CINAHL and OVID electronic databases. We used MeSH headings of "subclinical hypothyroidism", "thyroid", "depression", "thyroxine", "geriatric" and "elderly". We also reviewed references of the original article, reviews and clinical guidelines to identify additional eligible trials. Two independent reviewers (LHH and LLL) screened the titles and abstracts obtained through the electronic search and analysed the full-text articles. All duplicates were removed. Whenever needed, we contacted the authors to obtain either the full-text article or for clarification of the missing data. If the data were not provided numerically, it would be read off graphs. Two reviewers (LHH and LLL) extracted data from eligible studies independently using standard template, including authors, country of study conduct, study design, sample size, age, mean TSH levels, prevalence of major depression disorder (MDD) and the depression scores (based on the different depression scoring systems).

The analyses were divided into three parts. For part I, we examined the prevalence of depression in individuals with $\mathrm{SCH}$ compared with healthy controls. We also evaluated the mean depression scores among individuals with $\mathrm{SCH}$, compared with their euthyroid counterparts based on the depression scales used. We performed a subgroup analysis on geriatric population, defined as those aged 60 years and above according to the United Nation's classification [28]. For part II, we analysed the mean TSH level in individuals with depression compared with those without underlying psychiatric disorders. For part III, we evaluated the effect of levothyroxine replacement therapy on depressive symptoms among individuals with $\mathrm{SCH}$.

\section{Study selection}

For part I, we included studies which reported individuals who were diagnosed with $\mathrm{SCH}$. Only case-control studies that either compared the prevalence of depression or the mean depression scores in $\mathrm{SCH}$ cohort with euthyroid/healthy controls were eligible. We excluded studies that included individuals who had been treated for thyroid disorders. Among the 15 studies included, there were nine questionnaires used to evaluate depression. Beck Depression Inventory (BDI) scoring and Hamilton Depression Rating Scale (HDRS) were the most commonly administered questionnaires, which were analysed in current meta-analysis.

For part II, we included only studies that assessed individuals with depression using standard depression assessment tools, such as the HDRS, Structural Clinical Interview for Diagnostic and Statistical Manual of Mental Disorders, Third Edition, Revised (DSM-III-R) and Fourth Edition (DSM-IV), and compared the mean TSH with those not known to have psychiatric disorders.

For part III, either randomized controlled trials or case-control studies that evaluated the effect of levothyroxine therapy in individuals with $\mathrm{SCH}$ and coexistent depression were included. Similar to part I, we analysed studies which used BDI and/or HDRS scoring only.

\section{Quality assessment}

Two reviewers (LHH and LLL) independently appraised the quality of reporting of all included studies using the Newcastle-Ottawa Scoring (NOS) Scale for Case-Control Studies (Appendix). Any discrepancies were resolved by a third reviewer (LHS). The NOS scale was developed to assess the quality of non-randomized case-control studies for interpretation of meta-analysis results. It uses a "star system" which judges the studies in three broad categories, namely the selection of study group, group comparability and ascertainment of outcome of interest ("Exposure"). Each study can be awarded a maximum of one star for each numbered item (four in "Selection" category and three in "Exposure" category), and a maximum of two stars in the "Comparability" category. The maximum score is 10 .

\section{Statistical analysis}

All data analyses were performed using Stats Direct (version 2.7.9). Study characteristics were summarized. Descriptive statistics were shown as either mean \pm standard deviation (SD), median (interquartile range, IQR) or 
number (percentages). We calculated the prevalence of depression in patients with $\mathrm{SCH}$. The presence of heterogeneity between the trials was tested using the $I^{2}$ statistic. An $I^{2}$ value of more than $75 \%$ indicates significant heterogeneity. Due to the moderate and high heterogeneity $\left(I^{2} \geq 80 \%\right.$ and $\geq 90 \%$, respectively), data were pooled using the DerSimonian-Laird random-effects modelling. Pooled effect size $(\mathrm{d}+)$ was presented along with $95 \%$ confidence interval (CI) if the mean and SD of endpoint measures were reported in original articles. If the Cochrane $\mathrm{Q}$ test result was significant, we pooled the data using the DerSimonian-Laird random-effects modelling; otherwise, Hedges-Olkin fixed-effects modelling was used.

\section{Results}

Figure 1 shows the flow of studies selection. Initial search identified 3647 articles and yielded 21 full-text articles after abstracts screening and duplicates removal. Out of these 21 articles, 15 were included in part I analysis, six into part II and III analyses, respectively.
Part I - prevalence of depression in $\mathrm{SCH}$

Table 1 summarizes the study characteristics. A total of 12,315 individuals (1700 [13.8\%] with $\mathrm{SCH}$ ) from 15 articles were included in this analysis. The sample sizes ranged from 22 to 8214. Six studies involved community-dwelling healthy individuals $[12,17,20,21$, $23,29]$ while the remaining nine single-centre studies recruited out-patients who were investigated for suspected SCH $[7,13-16,19,22,24,30]$. Eight studies reported the mean depression scores between individuals with $\mathrm{SCH}$ and healthy controls, of which five used HDRS [12, $13,15,16,22]$ and three used BDI [17, 23, 24]. All other studies used different but validated scales to diagnose depression.

Overall, individuals with $\mathrm{SCH}$ were older compared with healthy controls $(51.9 \pm 17.5$ vs. $50.2 \pm 17.4$ years, $p$ $=0.020$ ). The mean TSH in individuals with $\mathrm{SCH}$ was significantly higher than healthy controls $(16.20 \pm 24.75$ vs. $2.09 \pm 0.57 \mathrm{mIU} / \mathrm{L} ; p<0.001)$. Six studies found a higher prevalence of depression among individuals with SCH compared with controls [7, 12, 14, 19, 23, 24], although only three studies achieved statistically significant difference [7, 14, 30]. Five studies showed higher

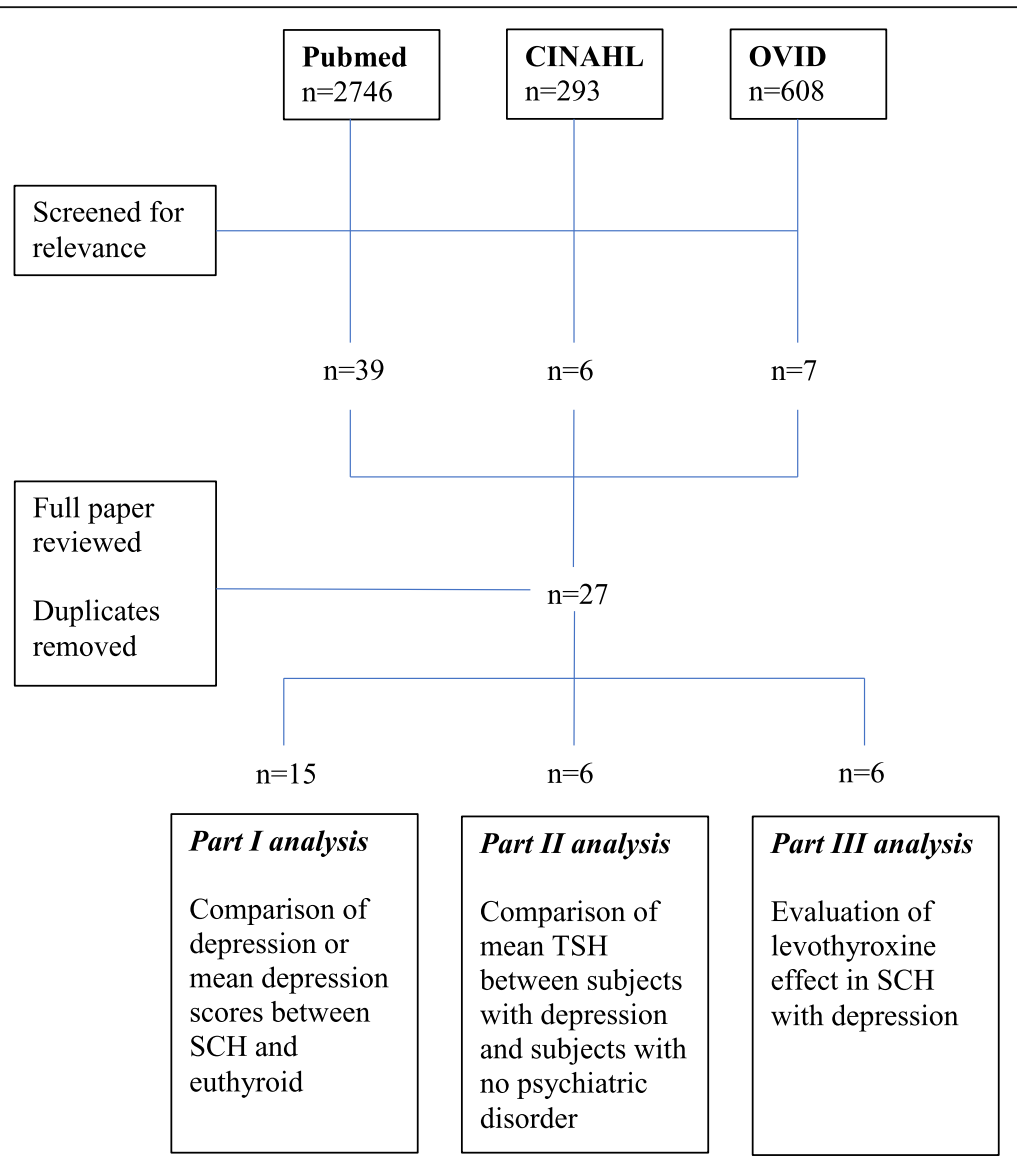

Fig. 1 PRISMA search strategy 


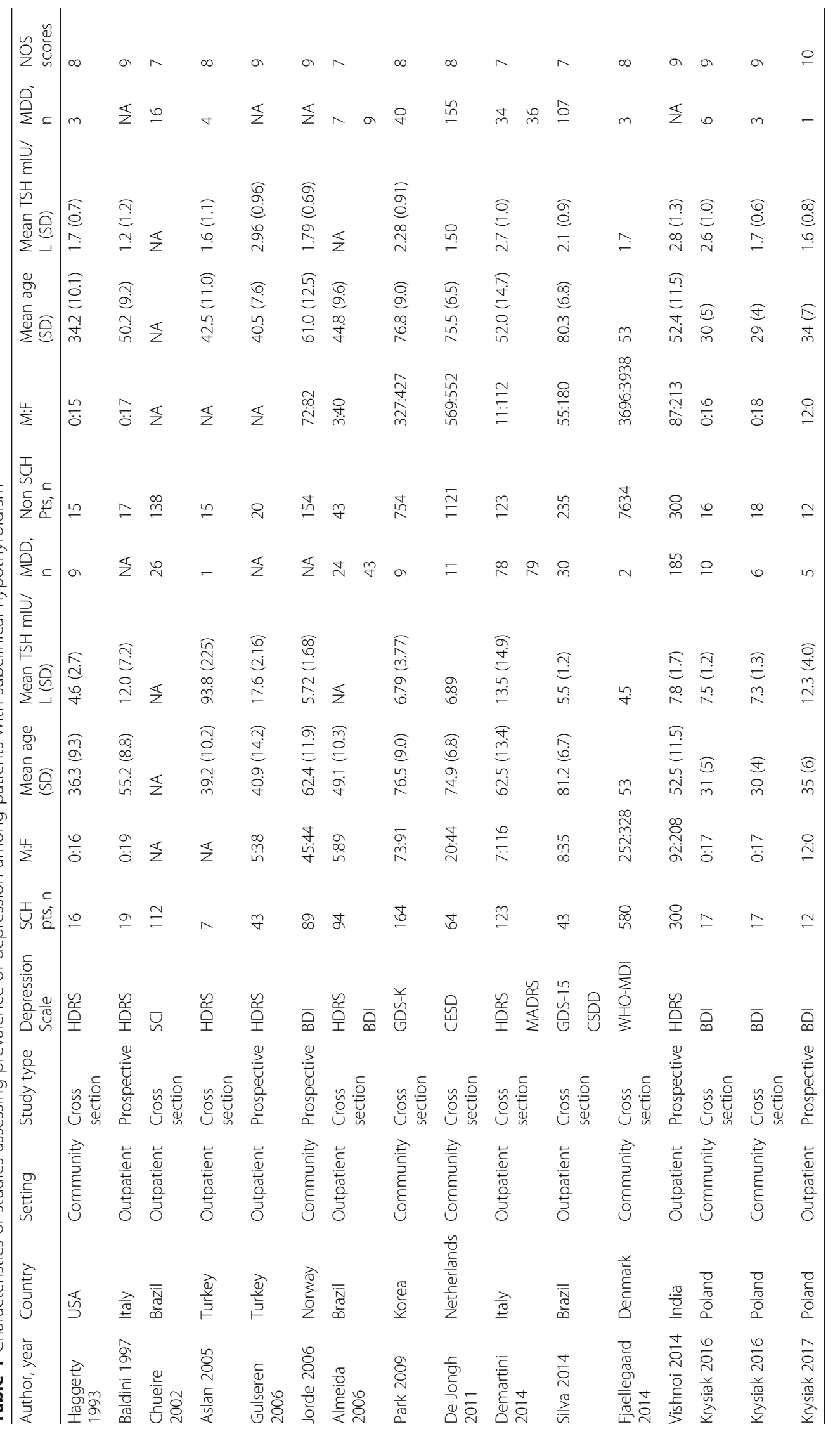


depression scores among patients with $\mathrm{SCH}$ than control group [12, 16, 22-24]. Five other studies showed no difference in the number of individuals with depression between $\mathrm{SCH}$ and control group $[8,15,20,21$, $30]$, whereas three found no difference in the depression scores [13, 15, 17]. However, pooled analysis showed that individuals with $\mathrm{SCH}$ had higher risk of depression compared with euthyroid controls (relative risk 2.36, 95\% CI 1.84 to $3.02 ; p<0.001$ ) (Fig. 2). Compared with healthy controls, there was no significant difference in the depression scores among individuals with $\mathrm{SCH}$, using either BDI scoring (10.85 \pm 4.97 vs. $8.1 \pm 2.82$; $p=0.126)$ or HDRS scale $(8.02 \pm$ 2.44 vs. $5.66 \pm 2.59 ; p=0.312$, $95 \%$ CI -2.22 to 6.70$)$.

In geriatric cohort with $\mathrm{SCH}$, four studies evaluated the prevalence of depression $[8,14,20,30]$, of which two recruited eligible individuals from single centre out-patient clinics $[14,30]$ and another two involved community-dwelling healthy controls [8, 20]. Their mean age did not differ from the euthyroid controls $(77.5 \pm 3.3$ vs. $77.5 \pm 2.5$ years; $p=0.770)$. The mean TSH was higher among $\mathrm{SCH}$ individuals than euthyroid controls $(6.15 \pm 0.91$ vs. $2.19 \pm 0.13$ $\mathrm{mIU} / \mathrm{L} ; p<0.001)$. Two studies found a higher prevalence of depression between elderly with $\mathrm{SCH}$ compared to controls $[14,30]$. When we pooled the data from these four studies, elderly individuals with $\mathrm{SCH}$ had a 1.7 -fold higher risk of depression than healthy controls (odds ratio $1.72,95 \%$ CI 1.10 to $2.70 ; p=$ 0.020) (Fig. 3).

\section{Part II - TSH level in depression}

Table 2 shows the characteristics of seven cross-sectional articles involving 7135 individuals, of whom 4942 (80.3\%) were men. Three studies recruited individuals who were hospitalized for psychiatric disorder without prevalent diseases such as metabolic, autoimmune and other endocrine diseases, infections and inflammatory disorders [31-33]. Two studies involved individuals seen in the psychiatric out-patient clinics [34, 35], three from psychiatric wards [31-33] whereas the other two studies selected individuals from the elderly community [36, 37]. All studies reported mean TSH of the study cohort. Five studies reported the prevalence of $\mathrm{SCH}$ among those diagnosed with depression $[31-33,35,36]$.

Among 753 (10.6\%) individuals with depression, 429 (57.0\%) were men. The mean age was higher among individuals with depression than healthy controls $(56.6 \pm$ 13.3 vs. $52.2 \pm 15.9$ years; $p=0.180$ ). There was no difference in mean TSH between individuals with depression and healthy controls $(2.30 \pm 1.18$ vs. $2.13 \pm 0.72 \mathrm{mIU} / \mathrm{L}$; $p=0.513)$.

Part III - effect of levothyroxine on depressive symptoms Six papers which involved a total of 266 individuals assessed the improvement of depression scores with levothyroxine therapy in the $\mathrm{SCH}$ cohort. Three papers utilized BDI scoring $[17,24,38]$, whereas the remaining three used HDRS [13, 16, 22].

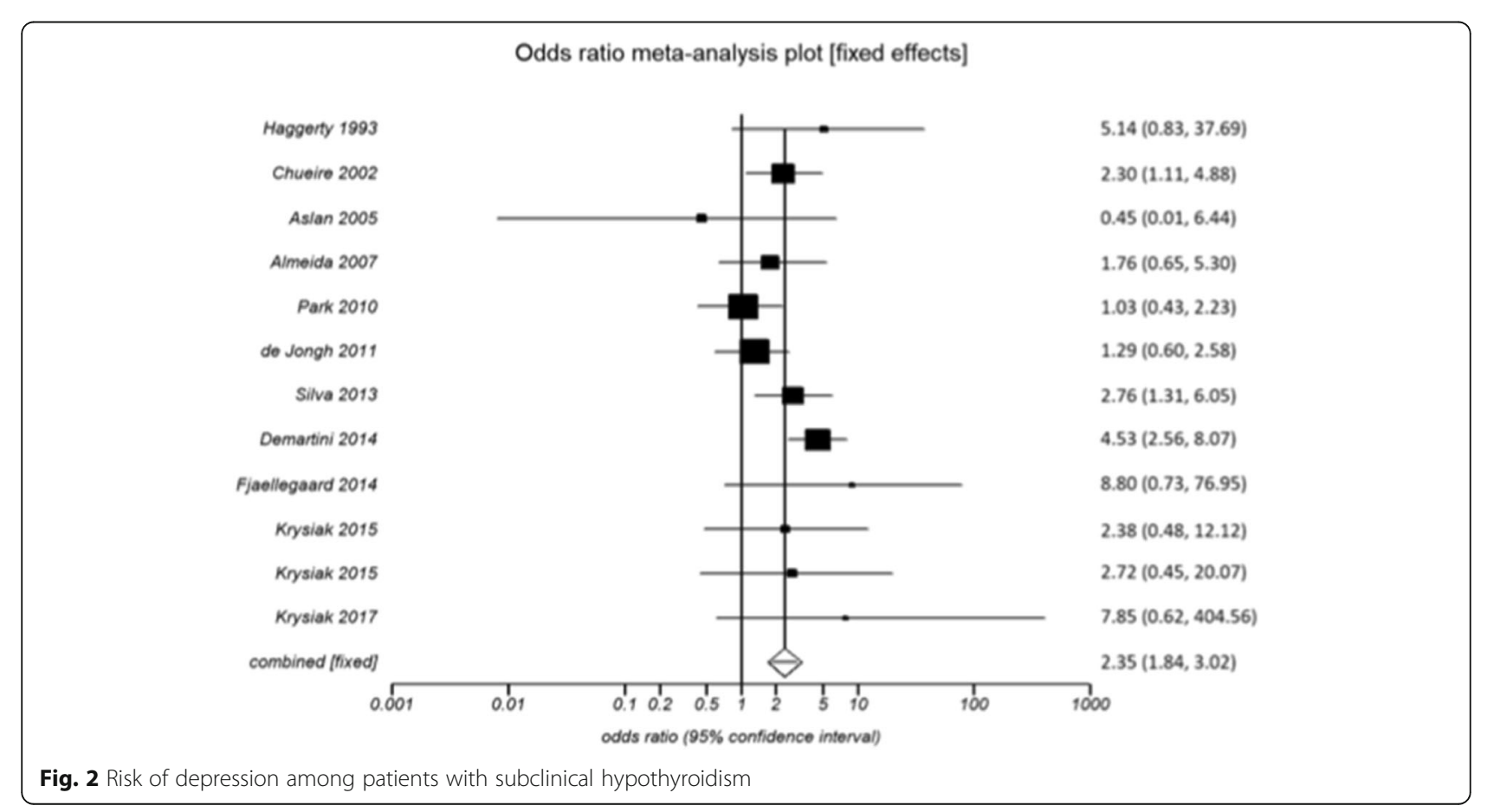




\section{Odds ratio meta-analysis plot [random effects]}

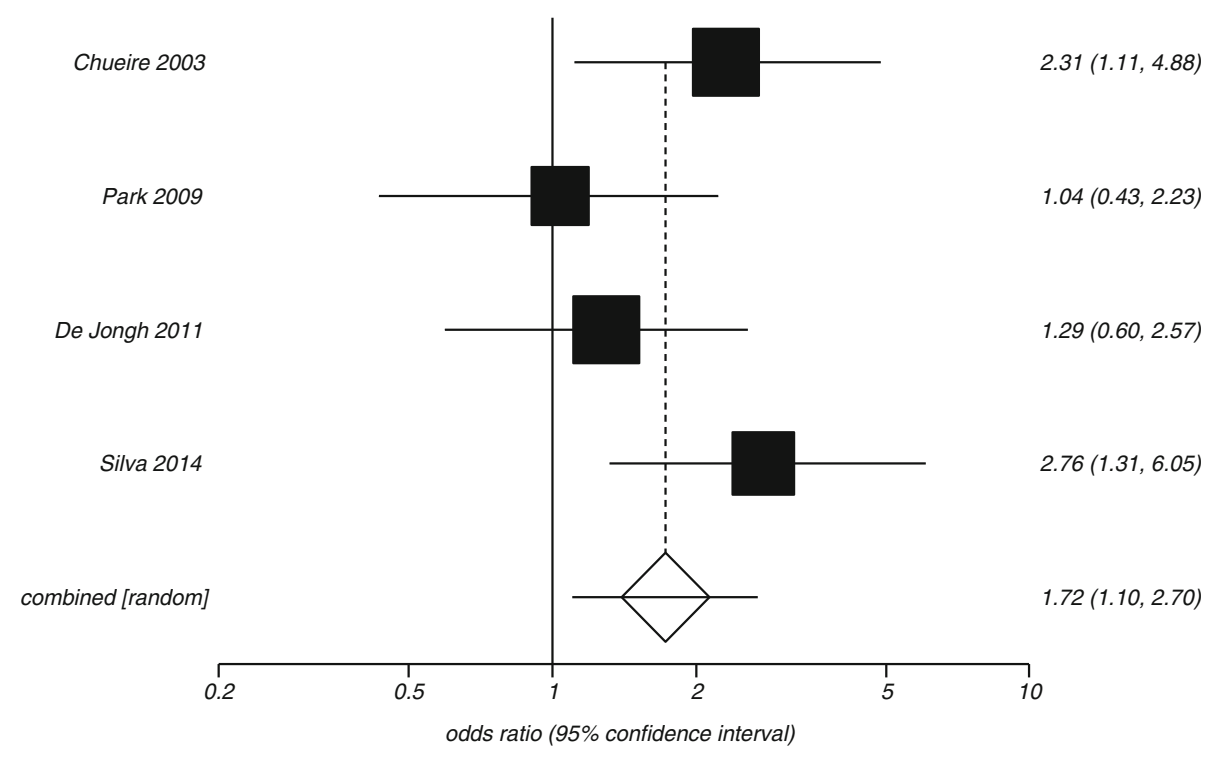

Fig. 3 Risk of depression among geriatric patients with subclinical hypothyroidism

The duration of intervention with levothyroxine therapy in these studies ranged from 2 to 12 months, with a mean duration of $5.95 \pm 4.09$ months. All but one study [17] reported a significant improvement in TSH with levothyroxine therapy (pooled $\mathrm{d}+=-8.09,95 \% \mathrm{CI}-12.56$ to $-3.63 ; p<0.001$ ). Three studies showed significant reduction in depression scores, from $10.3 \pm 4.6$ pre-treatment to $6.3 \pm 3.4$ post treatment, $p=0.00$ (HDRS) [22], from $8.3 \pm 5.2$ pre-treatment to $5.8 \pm 4.9$ post-treatment $p<0.05$ (HDRS) [16], and from $16.79 \pm 13.25$ pre-treatment to $12.37 \pm 10.01$ post-treatment, $p=0.04$ (BDI) [38]. However, pooled analysis using random-effects modelling revealed no significant improvement in either BDI scores (pooled $d+=-1.05,95 \%$ CI -2.72 to $0.61 ; p=0.215$ ) (Fig. 4) or HDRS (pooled $\mathrm{d}+=-2.38$, $95 \%$ CI -4.86 to $0.10 ; p=0.060$ ) (Fig. 5).

\section{Discussion}

Present updated meta-analysis of 21 studies reported nearly 2.5 -fold excess risk of depression in adults with $\mathrm{SCH}$, particularly in elderly population, compared with

Table 2 Characteristics of studies assessing TSH level in depression

\begin{tabular}{|c|c|c|c|c|c|c|c|c|c|c|c|c|c|}
\hline Author, year & Country & Setting & $\begin{array}{l}\text { Depression } \\
\text { Scale }\end{array}$ & $\begin{array}{l}\text { MDD } \\
\text { pts, n }\end{array}$ & $M: F$ & $\begin{array}{l}\text { Mean age } \\
\text { (SD) or age } \\
\text { range }\end{array}$ & $\begin{array}{l}\mathrm{SCH} \\
\text { pts, } \\
\text { n }\end{array}$ & $\begin{array}{l}\text { Mean } \\
\text { TSH mlU/ } \\
\text { L (SD) }\end{array}$ & $\begin{array}{l}\text { Non } \\
\text { MDD } \\
\text { pts, n }\end{array}$ & $M: F$ & $\begin{array}{l}\text { Mean age } \\
\text { (SD) or age } \\
\text { range }\end{array}$ & $\begin{array}{l}\text { Mean } \\
\text { TSH mlU/ } \\
\text { L (SD) }\end{array}$ & $\begin{array}{l}\text { NOS } \\
\text { score }\end{array}$ \\
\hline Boral 1980 & India & Out-patient & NA & 31 & $16: 15$ & $22-52$ & NA & $\begin{array}{l}4.58 \\
(1.17)\end{array}$ & 31 & $16: 15$ & $22-52$ & $\begin{array}{l}3.07 \\
(0.334)\end{array}$ & 8 \\
\hline Maes 1993 & Belgium & In-patient & HDRS & 57 & $20: 37$ & $54.2(1.7)$ & 0 & $0.99(0.1)$ & 69 & $33: 36$ & $40.8(1.4)$ & $\begin{array}{l}1.67 \\
(0.11)\end{array}$ & 8 \\
\hline Custro 1994 & Italy & In-patient & $\mathrm{BDI}$ & 9 & $0: 9$ & $30-69$ & 5 & $1.73(0.3)$ & 38 & $0: 38$ & 49.9 & $\begin{array}{l}1.17 \\
(0.05)\end{array}$ & 7 \\
\hline $\begin{array}{l}\text { Vandoolaeghe } \\
1997\end{array}$ & Belgium & In-patient & HDRS & 36 & $20: 16$ & $50.3(14.0)$ & 1 & $\begin{array}{l}1.44 \\
(1.02)\end{array}$ & 15 & $10: 5$ & $47.5(15.0)$ & $\begin{array}{l}1.73 \\
(0.99)\end{array}$ & 8 \\
\hline Saxena 2000 & India & Out-patient & NA & 32 & 21:11 & $36.2(11.8)$ & 6 & $\begin{array}{l}3.51 \\
(1.78)\end{array}$ & 11 & $5: 6$ & $30.54(12.6)$ & $\begin{array}{l}3.27 \\
(0.97)\end{array}$ & 8 \\
\hline Almeida 2011 & Australia & Community & GDS & 189 & 189:0 & $75.9(4.3)$ & 17 & $2.2(1.3)$ & 3742 & $3742: 0$ & $75.2(4.1)$ & $2.3(2.0)$ & 8 \\
\hline Saltevo 2015 & Finland & Community & $\mathrm{BDI}$ & 236 & $0: 236$ & $61(9)$ & NA & $\begin{array}{l}1.97 \\
(1.38)\end{array}$ & 1114 & $0: 1114$ & $59(8)$ & $\begin{array}{l}1.92 \\
(1.18)\end{array}$ & 8 \\
\hline Saltevo 2015 & Finland & Community & $\mathrm{BDI}$ & 163 & 163:0 & $62(9)$ & NA & $\begin{array}{l}1.94 \\
(1.25)\end{array}$ & 1136 & $1136: 0$ & $60(8)$ & $\begin{array}{l}1.87 \\
(1.24)\end{array}$ & 8 \\
\hline
\end{tabular}


Effect size meta analysis plot [random effects]

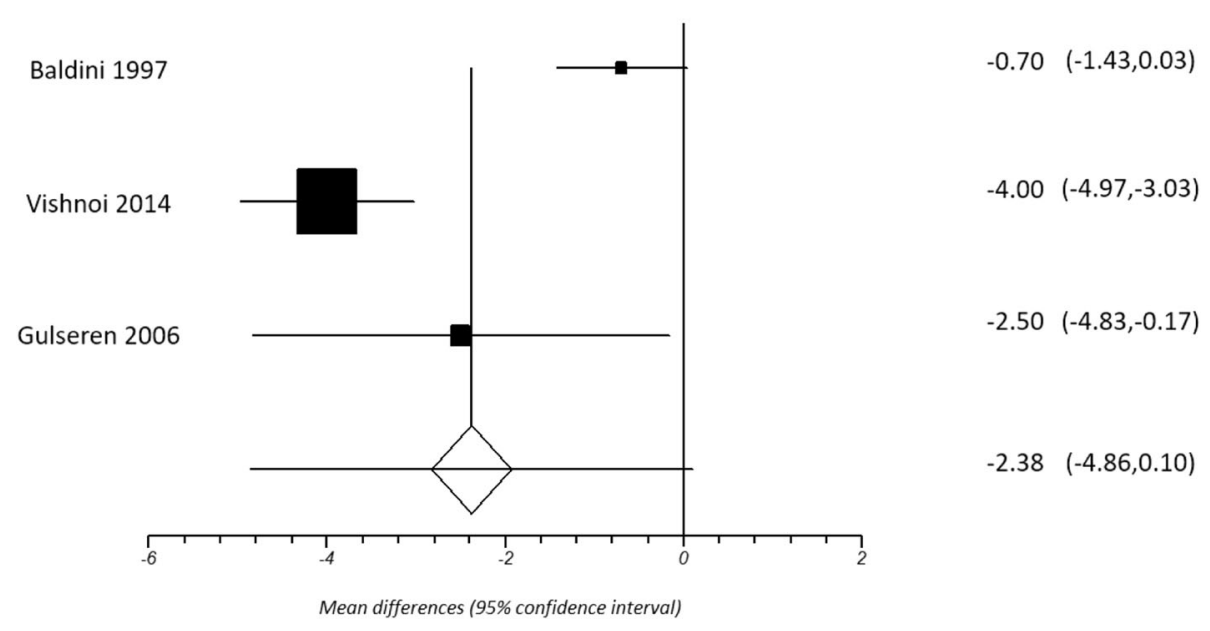

Fig. 4 Changes in BDI scores with levothyroxine treatment

their euthyroid counterparts. Our findings can potentially influence the clinical practice and improve the quality of life of patients.

The association between mood disorders and changes in the HPT axis has been recognized, although this is frequently reported in individuals with overt hyper -/hypothyroidism [5, 39-41]. In the central nervous system, alterations in hormones levels such as somatostatin and serotonin, can result in neuropsychiatric disturbances [42]. Existing evidence also suggests that these mechanisms can potentially affect the HPT axis and thus, explain the association between $\mathrm{SCH}$ and depression. Several studies reported a reduction in the somatostatin level in cerebrospinal fluid, leading to increased TSH level among individuals with depression [43, 44].
On the other hand, serotonin deficiency, which is also commonly seen in those with depression, has been postulated to cause alterations in the HPT axis [45]. Taken together, $\mathrm{SCH}$ and depression may share common biological mechanisms, which is in support of our findings.

Traditionally, depression is reported among people aged 35-45 years [46]. Of note, it has become increasingly common in the elderly as normal aging itself is associated with biochemical changes in the HPT axis. The secretion of thyroid hormones is reduced with increasing age, with a lower fT3 level but a relatively unchanged fT4 concentration. Compared with the younger population, higher TSH level is seen in the elderly due to reduced fT4 degradation and its peripheral conversion to fT3, with subsequent positive feedback to the HPT axis [47]. Individuals with overt

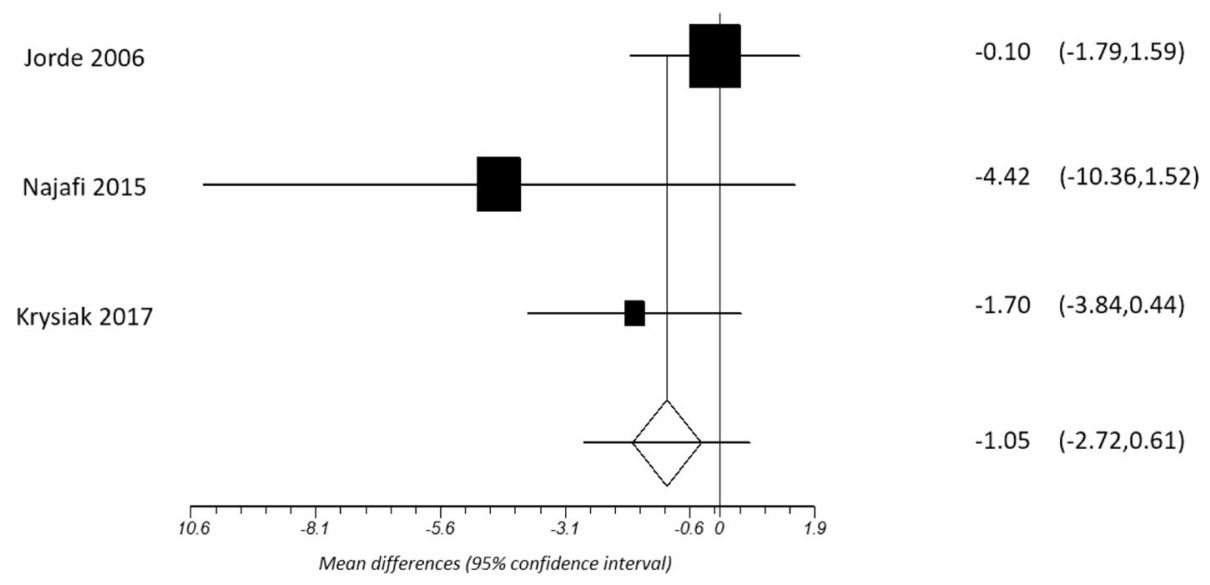

Fig. 5 Changes in HDRS scores with levothyroxine treatment 
hypothyroidism experience a wide variety of clinical signs and symptoms including cold intolerance, weight gain, cognitive dysfunction and mood disturbances [48, 49]. It is important to note that only up to $30 \%$ of individuals with $\mathrm{SCH}$ share similar clinical features [50], with the elderly group experience even fewer and more subtle complaints, which results in a delayed diagnosis of SCH [51]. Given the world population ageing and an increased risk of depression in the elderly with $\mathrm{SCH}$ as shown in our analysis [52], there is an urgent need for TSH and depression screening in this vulnerable population, in order to improve health and well-being for all.

Although our findings showed no significant difference in the serum TSH level between individuals with depression and healthy controls, this could possibly be a phenomenon known as the "brain hypothyroidism" [6], which represented a low intracerebral fT3 concentration with normal peripheral thyroid hormones and TSH levels [53]. Physiologically, type II deiodinase converts fT4 to fT3 in the brain glial cells [54]. However, it has been postulated that depression can cause inhibitory effect on type II deiodinase, which leads to the conversion of fT4 to rT3 via type III deiodinase [55]. Furthermore, transthyretin, a serum transport protein for fT4 in cerebrospinal fluid, is reduced in individuals with refractory depression [53]. Ultimately, these result in decreased intracerebral fT3 and fT4 levels, along with a high rT3 concentration in cerebrospinal fluid that can also inactivate fT3 activity $[55,56]$. Nevertheless, further studies which examine the variations between intracerebral and peripheral thyroid hormones and TSH levels in different populations are required to allow a better understanding of this complex relationship.

Our meta-analysis did not show improvement in the symptoms of depression with the use of levothyroxine therapy among individuals with coexistent $\mathrm{SCH}$. There are several possible explanations. Of the six studies included, the duration of intervention was relatively short and heterogenous (mean: 6 months, range: 2-12 months), which might contribute to the differential effects seen with levothyroxine therapy. On the other hand, given a reduced activity of intracerebral type II deiodinase in depression, levothyroxine therapy might be converted to rT3 that could exacerbate the existing intracerebral fT3 deficiency. In a seminal series of nine individuals with refractory depression, on top of antidepressant and levothyroxine therapy, additional administration of liothyronine was associated with marked improvement in the symptoms of depression in seven of them [57]. To date, the evidence related to the effect of normalization in thyroid hormones and TSH level in depression is inconclusive, perhaps due to the type of thyroid hormone replacement therapy used (single or combination), severity of $\mathrm{SCH}$ and depression, timing and duration of intervention.
To the best of our knowledge, our report has explored further in details the relationship between $\mathrm{SCH}$ and depression, by including the geriatric cohort and examining the effect of levothyroxine therapy in individuals with these co-existing illnesses. Importantly, our analysis indicated a clear negative impact of $\mathrm{SCH}$ in depression. However, our study has a few limitations. Meta-analyses are known to be confounded by the comprehensiveness of search strategy, reporting quality of included studies, publication bias and exclusion of non-English articles. In this analysis, explicit criteria were applied in our extensive literature search and investigators were contacted for clarification whenever necessary. Besides, the study populations were considerably older with a mean age of 52 years, which could limit the generalizability of our results.

\section{Conclusions}

Our findings favor early and routine screening for depression among individuals with $\mathrm{SCH}$ especially the elderly, to prevent morbidity and mortality. However, the use of levothyroxine therapy among people with depression need to be considered carefully on an individual basis, weighing the risks and benefits of the treatment. More well-designed population-based prospective studies or randomized controlled trials are needed to gain more insights of the pathogenesis and natural history of depression in $\mathrm{SCH}$, as well as the efficacy and safety of levothyroxine therapy to improve mood disorders among these high-risk individuals of varying age groups.

\section{Abbreviations \\ BDI: Beck depression inventory; DSM-III-R: Structural clinical interview for diagnostic and statistical manual of mental disorders, third edition, revised; DSM-IV: Structural clinical interview for diagnostic and statistical manual of mental disorders fourth edition; fT3: Free triiodothyronine; fT4: Free thyroxine; GDS: Geriatric depression scale; HDRS: Hamilton depression rating scale; HPT: Hypothalamic-pituitary-thyroid; MDD: Major depression disorder; NA: Not available; NOS: Newcastle-ottawa scoring; SCH: Subclinical hypothyroidism; TSH: Thyroid stimulating hormone}

\section{Acknowledgements}

Not applicable.

Funding

Not applicable.

\section{Availability of data and materials} Not applicable.

\section{Authors' contributions}

Data from eligible studies were extracted by two independent reviewers $(\mathrm{HHL}$ and $\mathrm{LLL})$. All extracted data were reviewed by HSL. Data analysis was performed by AY. HHL and LLL wrote the manuscript. All authors read and approved the final manuscript.

Ethics approval and consent to participate Not applicable.

Consent for publication Not applicable. 


\section{Competing interests}

The authors declare that they have no competing interests.

\section{Publisher's Note}

Springer Nature remains neutral with regard to jurisdictional claims in published maps and institutional affiliations.

\section{Author details}

${ }^{1}$ Faculty of Medicine and Health Sciences, University of Malaysia Sarawak(UNIMAS), Jalan Dato Muhammad Musa, 94300 Kota Samarahan, Sarawak, Malaysia. ${ }^{2}$ Division of Endocrinology, Department of Medicine, Faculty of Medicine, University of Malaya, Kuala Lumpur, Malaysia. ${ }^{3}$ Department of Psychological Medicine, Faculty of Medicine, University of Malaya, Kuala Lumpur, Malaysia. ${ }^{4}$ Clinical Academic Unit, Newcastle University Medicine Malaysia, Gelang Patah, Malaysia.

\section{Received: 26 September 2018 Accepted: 27 December 2018} Published online: 08 January 2019

\section{References}

1. Prince M, Patel V, Saxena S, Maj M, Maselko J, Phillips MR, et al. No health without mental health. Lancet (London, England). 2007;370(9590):859-77.

2. Brenes GA. Anxiety, depression, and quality of life in primary care patients. Prim Care Companion J Clin Psychiatry. 2007;9(6):437-43.

3. Oppenheimer JH, Schwartz HL. Molecular basis of thyroid hormonedependent brain development. Endocr Rev. 1997;18(4):462-75.

4. Brouwer JP, Appelhof BC, Hoogendijk WJ, Huyser J, Endert E, Zuketto C, et al. Thyroid and adrenal axis in major depression: a controlled study in outpatients. Eur J Endocrinol. 2005;152(2):185-91.

5. Constant EL, Adam S, Seron X, Bruyer R, Seghers A, Daumerie C. Hypothyroidism and major depression: a common executive dysfunction? J Clin Exp Neuropsychol. 2006;28(5):790-807.

6. Hage MP, Azar ST. The link between thyroid function and depression. J Thyroid Res. 2012;2012:590648.

7. Demartini B, Ranieri R, Masu A, Selle V, Scarone S, Gambini O. Depressive symptoms and major depressive disorder in patients affected by subclinical hypothyroidism: a cross-sectional study. J Nerv Ment Dis. 2014;202(8):603-7.

8. Park YJ, Lee EJ, Lee YJ, Choi SH, Park JH, Lee SB, et al. Subclinical hypothyroidism $(\mathrm{SCH})$ is not associated with metabolic derangement, cognitive impairment, depression or poor quality of life (QoL) in elderly subjects. Arch Gerontol Geriatr. 2010;50(3):e68-73.

9. Rugge B, Balshem H, Sehgal R, Relevo R, Gorman P, Helfand M. Screening and Treatment of Subclinical Hypothyroidism or Hyperthyroidism. AHRQ Comparative Effectiveness Reviews. Rockville (MD)2011.

10. Hak AE, Pols HA, Visser TJ, Drexhage HA, Hofman A, Witteman JC. Subclinical hypothyroidism is an independent risk factor for atherosclerosis and myocardial infarction in elderly women: the Rotterdam study. Ann Intern Med. 2000;132(4):270-8.

11. Singh S, Duggal J, Molnar J, Maldonado F, Barsano CP, Arora R. Impact of subclinical thyroid disorders on coronary heart disease, cardiovascular and all-cause mortality: a meta-analysis. Int J Cardiol. 2008;125(1):41-8.

12. Haggerty JJ, Jr., Stern RA, Mason GA, Beckwith J, Morey CE, Prange AJ, Jr. Subclinical hypothyroidism: a modifiable risk factor for depression? Am J Psychiatry 1993;150(3):508-510.

13. Baldini IM, Vita A, Mauri MC, Amodei V, Carrisi M, Bravin S, et al. Psychopathological and cognitive features in subclinical hypothyroidism. Prog Neuro-Psychopharmacol Biol Psychiatry. 1997;21(6):925-35.

14. Chueire VB, Silva ET, Perotta E, Romaldini JH, Ward LS. High serum TSH levels are associated with depression in the elderly. Arch Gerontol Geriatr. 2003;36(3):281-8.

15. Aslan S, Ersoy R, Kuruoglu AC, Karakoc A, Cakir N. Psychiatric symptoms and diagnoses in thyroid disorders: a cross-sectional study. Int J Psychiatry Clin Pract. 2005:9(3):187-92.

16. Gulseren S, Gulseren L, Hekimsoy Z, Cetinay P, Ozen C, Tokatlioglu B. Depression, anxiety, health-related quality of life, and disability in patients with overt and subclinical thyroid dysfunction. Arch Med Res. 2006;37(1):133-9.

17. Jorde R, Waterloo K, Storhaug H, Nyrnes A, Sundsfjord J, Jenssen TG. Neuropsychological function and symptoms in subjects with subclinical hypothyroidism and the effect of thyroxine treatment. J Clin Endocrinol Metab. 2006;91(1):145-53.
18. Roberts LM, Pattison H, Roalfe A, Franklyn J, Wilson S, Hobbs FD, et al. Is subclinical thyroid dysfunction in the elderly associated with depression or cognitive dysfunction? Ann Intern Med. 2006;145(8):573-81.

19. Almeida C, Brasil MA, Costa AJ, Reis FA, Reuters V, Teixeira $P$, et al. Subclinical hypothyroidism: psychiatric disorders and symptoms. Rev Bras Psiquiatr. 2007:29(2):157-9.

20. de Jongh RT, Lips P, van Schoor NM, Rijs KJ, Deeg DJ, Comijs HC, et al. Endogenous subclinical thyroid disorders, physical and cognitive function, depression, and mortality in older individuals. Eur J Endocrinol. 2011;165(4):545-54.

21. Fjaellegaard K, Kvetny J, Allerup PN, Bech P, Ellervik C. Well-being and depression in individuals with subclinical hypothyroidism and thyroid autoimmunity - a general population study. Nordic J Psychiatry. 2015;69(1):73-8.

22. Vishnoi G, Chakraborty B, Garda H, Gowda SH, Goswami B. Low mood and response to levothyroxine treatment in Indian patients with subclinical hypothyroidism. Asian J Psychiatr. 2014;8:89-93.

23. Krysiak R, Drosdzol-Cop A, Skrzypulec-Plinta V, Okopien B. Sexual function and depressive symptoms in young women with thyroid autoimmunity and subclinical hypothyroidism. Clin Endocrinol. 2016;84(6):925-31.

24. Krysiak R, Szkrobka W, Okopien B. The effect of I-thyroxine treatment on sexual function and depressive symptoms in men with autoimmune hypothyroidism. Pharmacol Rep. 2017:69(3):432-7.

25. Garber JR, Cobin RH, Gharib H, Hennessey JV, Klein I, Mechanick Jl, et al. Clinical practice guidelines for hypothyroidism in adults: cosponsored by the American Association of Clinical Endocrinologists and the American Thyroid Association. Thyroid. 2012;22(12):1200-35.

26. Taylor PN, Razvi S, Pearce SH, Dayan CM. Clinical review: A review of the clinical consequences of variation in thyroid function within the reference range. J Clin Endocrinol Metab. 2013;98(9):3562-71.

27. Pearce SH, Brabant G, Duntas LH, Monzani F, Peeters RP, Razvi S, et al. 2013 ETA guideline: Management of Subclinical Hypothyroidism. Eur Thyroid J. 2013;2(4):215-28.

28. DeSA U. World population prospects: the 2017 revision. New York: Population division of the department of economic and social affairs of the United Nations Secretariat; 2017.

29. Park YJ, Yoon JW, Kim Kl, Lee YJ, Kim KW, Choi SH, et al. Subclinical hypothyroidism might increase the risk of transient atrial fibrillation after coronary artery bypass grafting. Ann Thorac Surg. 2009;87(6):1846-52.

30. SO ES, Chan IT, Lobo Santos MA, Cohen M, de La Roque PAM, da Silva Almeida J, et al. Impact of thyroid status and age on comprehensive geriatric assessment. Endocrine. 2014;47(1):255-65.

31. Custro N, Scafidi V, Lo Baido R, Nastri L, Abbate G, Cuffaro MP, et al. Subclinical hypothyroidism resulting from autoimmune thyroiditis in female patients with endogenous depression. J Endocrinol Investig. 1994;17(8):641-6.

32. Vandoolaeghe E, Maes M, Vandevyvere J, Neels H. Hypothalamic-pituitarythyroid-axis function in treatment resistant depression. J Affect Disord. 1997; 43(2): 143-50.

33. Maes M, Meltzer HY, Cosyns P, Suy E, Schotte C. An evaluation of basal hypothalamic-pituitary-thyroid axis function in depression: results of a largescaled and controlled study. Psychoneuroendocrinology. 1993;18(8):607-20.

34. Boral GC, Ghosh AB, Pal SK, Ghosh KK, Nandi DN. Thyroid function in different psychiatric disorders. Indian J Psychiatry. 1980;22(2):200-2.

35. Saxena J, Singh PN, Srivastava U, Siddiqui AQ. A study of thyroid hormones (t(3), t(4) \& tsh) in patients of depression. Indian J Psychiatry. 2000:42(3):243-6.

36. Almeida OP, Alfonso H, Flicker L, Hankey G, Chubb SA, Yeap BB. Thyroid hormones and depression: the health in men study. Am J Geriatr Psychiatry. 2011;19(9):763-70.

37. Saltevo J, Kautiainen H, Mantyselka P, Jula A, Keinanen-Kiukaanniemi S, Korpi-Hyovalti E, et al. The relationship between thyroid function and depressive symptoms-the FIN-D2D population-based study. Clin Med Insights Endocrinol Diabetes. 2015;8:29-33.

38. Najafi L, Malek M, Hadian A, Ebrahim Valojerdi A, Khamseh ME, Aghili R. Depressive symptoms in patients with subclinical hypothyroidism--the effect of treatment with levothyroxine: a double-blind randomized clinical trial. Endocr Res. 2015:40(3):121-6.

39. Prange AJ Jr, Wilson IC, Rabon AM, Lipton MA. Enhancement of imipramine antidepressant activity by thyroid hormone. Am J Psychiatry. 1969;126(4):457-69.

40. Whybrow PC, Prange AJ Jr, Treadway CR. Mental changes accompanying thyroid gland dysfunction. A reappraisal using objective psychological measurement. Arch Gen Psychiatry. 1969;20(1):48-63.

41. Rack SK, Makela EH. Hypothyroidism and depression: a therapeutic challenge. Ann Pharmacother. 2000;34(10):1142-5. 
42. Ortiga-Carvalho TM, Chiamolera MI, Pazos-Moura CC, Wondisford FE. Hypothalamus-pituitary-thyroid Axis. Compr Physiol. 2016;6(3):1387-428.

43. Rubinow DR, Gold PW, Post RM, Ballenger JC, Cowdry R, Bollinger J, et al. CSF somatostatin in affective illness. Arch Gen Psychiatry. 1983;40(4):409-12.

44. Bissette G, Widerlov E, Walleus H, Karlsson I, Eklund K, Forsman A, et al. Alterations in cerebrospinal fluid concentrations of somatostatinlike immunoreactivity in neuropsychiatric disorders. Arch Gen Psychiatry. 1986; 43(12):1148-51.

45. Kirkegaard C, Faber J. The role of thyroid hormones in depression. Eur J Endocrinol. 1998;138(1):1-9.

46. Jackson IM. The thyroid axis and depression. Thyroid. 1998;8(10):951-6.

47. Mariotti S, Franceschi C, Cossarizza A, Pinchera A. The aging thyroid. Endocr Rev. 1995;16(6):686-715

48. Chakera AJ, Pearce SH, Vaidya B. Treatment for primary hypothyroidism: current approaches and future possibilities. Drug Des Devel Ther. 2012;6:1-11.

49. Bauer M, Goetz T, Glenn T, Whybrow PC. The thyroid-brain interaction in thyroid disorders and mood disorders. J Neuroendocrinol. 2008;20(10):1101-14.

50. Joffe RT, Pearce EN, Hennessey JV, Ryan JJ, Stern RA. Subclinical hypothyroidism, mood, and cognition in older adults: a review. Int I Geriatr Psychiatry. 2013;28(2):111-8.

51. Davis JD, Stern RA, Flashman LA. Cognitive and neuropsychiatric aspects of subclinical hypothyroidism: significance in the elderly. Curr Psychiatry Rep. 2003;5(5):384-90

52. United Nations. Department of Economic and Social Affairs, Population division. World population ageing 2015 (ST/ESA/SER.A/390). 2015.

53. Hatterer JA, Herbert J, Hidaka C, Roose SP, Gorman JM. CSF transthyretin in patients with depression. Am J Psychiatry. 1993;150(5):813-5.

54. Bianco AC, Kim BW. Deiodinases: implications of the local control of thyroid hormone action. J Clin Invest. 2006;116(10):2571-9.

55. Kaplan MM. The role of thyroid hormone deiodination in the regulation of hypothalamo-pituitary function. Neuroendocrinology. 1984;38(3):254-60

56. Linnoila M, Cowdry R, Lamberg BA, Makinen T, Rubinow D. CSF triiodothyronine (rT3) levels in patients with affective disorders. Biol Psychiatry. 1983;18(12):1489-92

57. Cooke RG, Joffe RT, Levitt AJ. T3 augmentation of antidepressant treatment in T4-replaced thyroid patients. J Clin Psychiatry. 1992;53(1):16-8.

Ready to submit your research? Choose BMC and benefit from:

- fast, convenient online submission

- thorough peer review by experienced researchers in your field

- rapid publication on acceptance

- support for research data, including large and complex data types

- gold Open Access which fosters wider collaboration and increased citations

- maximum visibility for your research: over $100 \mathrm{M}$ website views per year

At $\mathrm{BMC}$, research is always in progress.

Learn more biomedcentral.com/submissions 